\title{
SEASONAL REPRODUCTIVE CYCLE AND VARIABILITY IN PLASMA TESTOSTERONE LEVELS IN THE DOMESTIC DUCK (Anas platyrhynchos)
}

\author{
CICLO REPRODUTIVO SAZONAL E VARIABILIDADE EM NÍVEIS DE \\ TESTOSTERONA NO PATO DOMÉSTICO (Anas platyrhynchos)
}

\section{Karina SIMÕES ${ }^{1}$; Antônio Marcos ORSI ${ }^{2}$; Bruno César SCHIMMING ${ }^{2}$; Edson José BENETTI ${ }^{1}$}

1. Departament of Morphology, Institute of Biological Sciences, Federal University of Goiás - UFG, Goiânia, Goiás, Brazil. simoesk@ufg.br; 2. Departament of Anatomy, Institute of Biosciences, São Paulo State University - UNESP, Botucatu, São Paulo, Brazil.

\begin{abstract}
Morphofunctional gonadal alterations constitute an annual cycle in birds during which four phases can be distinguished in the testes based on histological modifications in the seminiferous epithelium, called quiescence, recrudescence, reproduction and regression. The aim of the present investigation was to conduct a morphometric and morphological study of the seminiferous epithelium on the testis of domestic duck and to evaluate the plasma testosterone levels in order to determine the possible presence of a reproductive cycle in the tropical region. The study was conducted on 60 adult domestic ducks (Anas platyrhynchos), where five animals were sacrificed per month and the testes were removed and histologically and morphometrically studied. Blood samples of the five animals were collected monthly in the morning period and the testosterone levels were analyzed. Annual reproductive cycle of the domestic duck presented by four distinct phases, starting with the reproductive phase at the beginning of winter (July) and peak of reproduction in spring (October), accompanied by an increase in tubule seminiferous diameter, epithelium height, weight and testicular volume, followed by a regressive phase at the end of spring (November) and the beginning of summer (December). Testicular quiescence was observed during summer (January and February) and was followed by a phase of spermatogenic recrudescence, which lasted throughout autumn (March to June), corresponding to the longest phase of the cycle. Complete spermiogenesis in terms of spermatozoa maturation and spermiation was observed during the reproductive phase, coinciding with the plasma testosterone peak. At regressive phase an exfoliation of the seminiferous epithelium was observed, accompanied by a great amount of fibrillar collagen. A decrease in tubular seminiferous diameter and epithelium height was observed during testicular quiescence, with predominance of spermatogonia and Sertoli cells and a second plasma testosterone peak was also observed during this phase (January), probably representing the preparation for a gradual return to the spermatogenic process during recrudescence. The latter phase was characterized by gradual recovery of the seminiferous epithelium, accompanied by the increase of spermatogonia, onset of meiosis, and the presence of primary spermatocytes and maturing spermatids. In conclusion the domestic duck presented the testicular cycle divided in four distinct phases in the tropical region with testosterone peaks in the testicular quiescence and reproductive phases.
\end{abstract}

KEYWORDS: Reproductive cycle. Testosterone. Domestic duck.

\section{INTRODUCTION}

Reproduction in vertebrates is under endogenous regulation and generally depends also on environmental factors. Thus, existing reproductive models consists of alternating periods of gonadal activity and quiescence. In birds, the seasonal reproductive cycles are constant and are influenced by environmental factors, with the reproductive organs growing and regressing according to light, temperature, rainfall index and food availability (KEMP, 1973; SILVERIN, 1975), as well as being subject to constant variations according to geographical latitude and altitude (BREUCKER et al., 1989).

In birds with seasonal reproduction, the availability of mature gametes is restricted to a given time of the year and varies among different species. Morphofunctional gonadal alterations constitute an annual cycle during which four phases can be distinguished in the testes based on histological modifications in the seminiferous epithelium, called quiescence, recrudescence, reproduction (proliferation) and regression (BREUCKER et al., 1989; FUENZALIDA et al., 1989;; BARALDI-ARTONI et al., 1997).

Many studies have been conducted on the influence of different photoperiods on the control of the reproductive functions of female (beginning and maintenance of egg laying) and male (semen production) birds in view of their economic interest. In aviary with controlled lighting, the duration of the day and of the light: dark cycle should be decided for each phase of the reproductive cycle and according to the producer's objectives. On this basis, it is of fundamental importance to determine 
the testicular cycle of each bird and some histological parameters of the testicular structure have been explored. Among them are the seminiferous tubule diameter, height of seminiferous epithelium, thickness of the tunica albuginea, number of interstitial cells or germ cells, and nuclear diameter of germ cells (FUENZALIDA et al., 1989).

The length of the photoperiod is responsible for gonadal development and synchronization of reproduction, acting on the hypophysis and hypothalamus and stimulating gonadotrophins. The gonadotrophins follicle-stimulating hormone (FSH) and luteinizing hormone (LH) play a role in the development of germ cells and in the formation and release of gonadal steroid hormones. FSH stimulates spermatogenesis, while LH stimulates Leydig cells to produce testosterone, a steroid necessary for spermatozoa maturation (BENTLEY, 1998).

In birds, testosterone is responsible for the stimulation of territorial aggressiveness, development of secondary sexual characteristics, production of spermatozoa, and male sexual behavior (HAU et al., 2000). In general, circulating plasma testosterone levels increase close to spring and remain elevated during the reproductive period (FOLLETT, 1984; WINGFIELD, FARNER, 1993; HAU et al., 2000). In contrast, little or no changes in testosterone levels during the reproductive cycle have been observed in some terrestrial tropical birds (WINGFIELD et al., 1990; LORMÉE et al., 2000). It is generally acknowledged that seasonal fluctuations in the morphology and function of bird testes are primarily regulated by seasonal changes in circulating concentrations of testosterone which mediates its action via the androgen receptor. However, it has not yet been elucidated whether gonadal sensitivity to androgens also varies across the bird reproductive cycle (LESKA et al., 2012).

On this basis, the aim of the present investigation was to conduct a morphometric and morphological study of the seminiferous epithelium on the testis of domestic duck and to evaluate the plasma testosterone levels in order to determine the possible presence of a reproductive cycle in the tropical region, correlating them with the different seasons of the year.

\section{MATERIAL AND METHODS}

The study was conducted on 60 adult domestic ducks (Anas platyrhynchos) weighing 2.5 to $4.0 \mathrm{~kg}$ obtained from a commercial duck farm

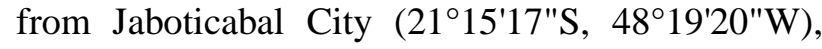
São Paulo State, Brazil. The animals were euthanized along a period one-year by Ketamine choridrate $(20 \mathrm{mg} / \mathrm{Kg})$ and Xilazine choridrate $(1.5$ $\mathrm{mg} / \mathrm{Kg}$ ) overdose, intramuscularly applied. The reproductive organs were removed by abdominal laparotomy and evisceration of the gastrointestinal tract. The project was approved by the Ethics Committee on Animal Use of UFG (CEUA-UFG, 024/11).

\section{Morphological Analysis}

For the study of the annual reproductive cycle, five animals were euthanized per month and the testes were removed, sectioned longitudinally, immersed McDowell's solutions (MCDOWELL, TRUMP, 1976) for $24 \mathrm{~h}$, and embedded in Histosec ${ }^{\circledR}$ (Merck, USA) or Historesin ${ }^{\circledR}$ (Leica, Germany). Histological 3- to 5- $\mu \mathrm{m}$ thick sections were stained with Hematoxylin-eosin, Heidenhain Schleicher and $1 \%$ Toluidine blue- $0.5 \%$ basic Fuchsin. The sections were analyzed and documented by Olympus BX-41 Photomicroscope.

\section{Morphometric Analysis}

For morphometric analysis, the testes were removed, weighted in semi-analytical balance (Acculab, USA) and the total volume of each testis was calculated using the formula for the volume of a ellipsoid: $\mathrm{V}=4 / 3 \times \pi \times \mathrm{a} \times \mathrm{b}^{2}$, where $\mathrm{a}=$ semiprolate axis and $b=$ semioblate axis of testis (MIRAGLIA, HAYASHI, 1993). The average volume of testis for each animal was calculated using the average measurements for the major and minor axes for right and left testis with a digital paquimeter (Mitutoyo, Japan).

For morphometric analysis of seminiferous tubules diameter and height of the seminiferous epithelium in the different phases of the reproductive cycle were used the same five monthly animals, and six random histological sections of testes per animal, resulting in 30 diameter of the measures seminiferous tubules/animal and 150 height measurements of the seminiferous epithelium/animal through Computational Program Image Analysis Image-Pro Plus (Media Cybernetics, USA).

\section{Testosterone Assay}

Blood samples of the five animals were collected monthly in the morning period by puncture of the left cardiac ventricle with a heparinized syringe. After refrigerated centrifugation, plasma was stored at $-20^{\circ} \mathrm{C}$ for later determination of the androgen. Total plasma testosterone was determined by radioimmunoassay using the commercial Coat-A-Count ${ }^{\circledR}$ kit 
(Diagnostic Products Corporation, Los Angeles, USA) in duplicate for an eventual countercheck of the results. A 50- $\mu \mathrm{l}$ plasma aliquot and $1.0 \mathrm{ml}$ iodide $^{125}$ were added to each tube, and the tubes were incubated for $3 \mathrm{~h}$ at $37^{\circ} \mathrm{C}$ and decanted for $1 \mathrm{~h}$. Samples were read for $1 \mathrm{~min} / \mathrm{sample}$ in a gamma counter (DPC, USA). Interassay variation was within $11 \%$, and intraassay variation within $9.6 \%$.

\section{Statistical Analysis}

The data were analyzed statistically by analysis of variance (ANOVA) and the 5\% Tukey test using the SAS ${ }^{\circledR}$ (Statistical Analyses System) software.

\section{RESULTS}

The annual reproductive cycle of Anas platyrhynchos can be divided into the following four successive phases based on morphological and morphometric modifications in the seminiferous epithelium: reproduction (proliferation), regression, quiescence, and recrudescence.

The reproductive phase started in winter (July) and reached its peak in spring (October). This phase was characterized by the presence of complete spermatogenesis, wide seminiferous tubules containing spermatogonia, primary spermatocytes in different stages of meiotic prophase I, spermatid differentiation, and spermatozoa in the tubular lumen (Figure 1). Still during the reproductive phase, a thin tunica albuginea and poorly developed interstitium containing Leydig cells and blood vessels were noted (Photos 1, 2).

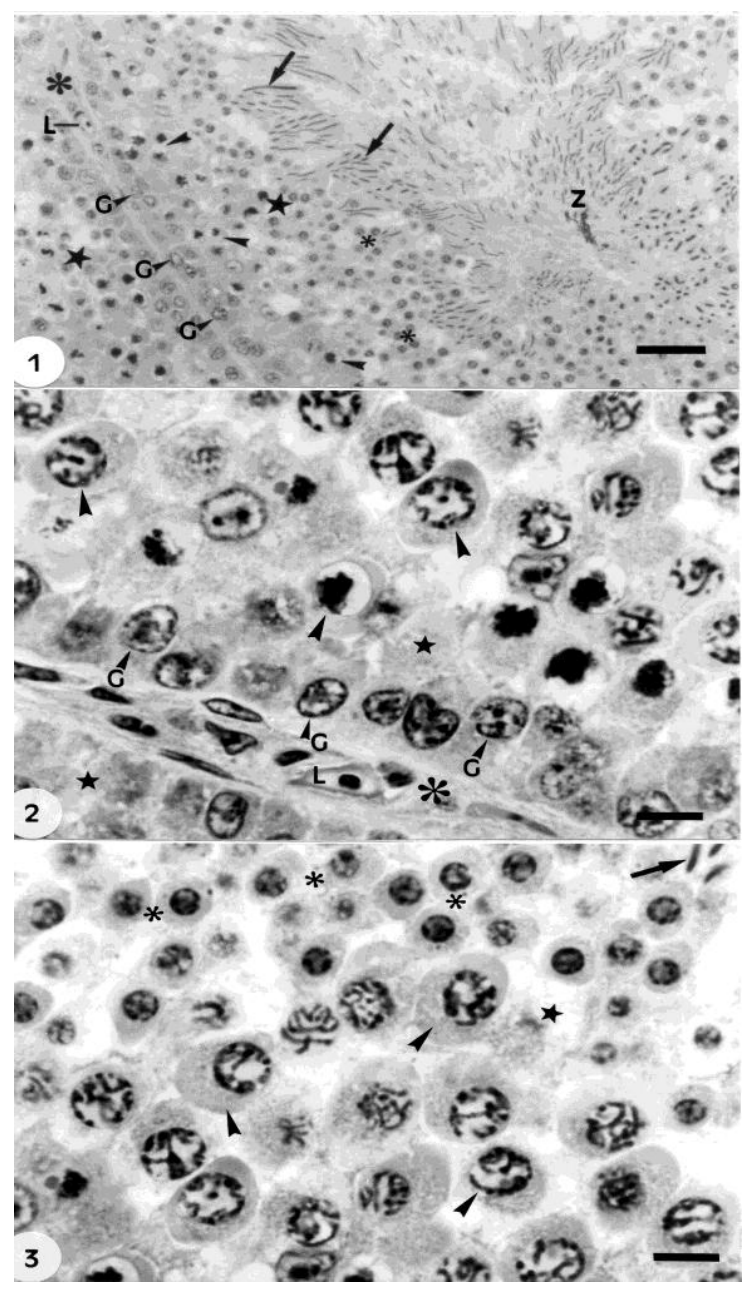

Figure 1. Phase of reproduction showing wide seminiferous tubules (stars), spermatogonia (G), primary spermatocytes (large arrowheads), and round spermatids (small asterisks) and elongated spermatids (arrows). Note spermatozoa (Z) in the tubular lumen in Fig. 1, the interstitium (large asterisks) in Figs. 1, 2 and Leydig cell (L) in Figs. 1, 2. Bar $=10 \mu \mathrm{m}$ (Fig. 1); Bar $=2,5 \mu \mathrm{m}$ (Figs. 2, 3) . 


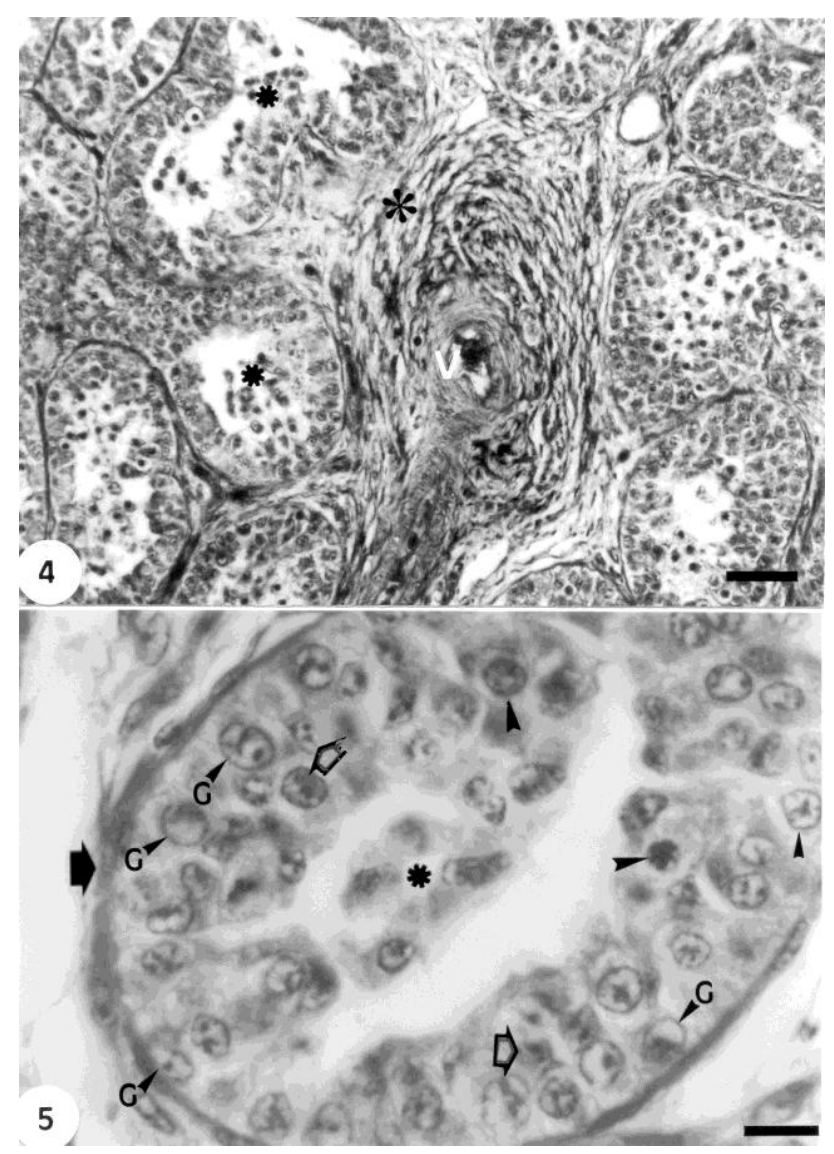

Figure 2. Phase of regression showing exfoliation of the seminiferous epithelium in the tubular lumen (roses), the interstitium (asterisk) with a predominance of fibrillar collagen, and a blood vessel (V) in photo $4($ Bar $=10 \mu \mathrm{m})$ and Sertoli cells (thick arrows), spermatogonia $(\mathrm{G})$, primary spermatocytes (large arrowheads), a developed basement membrane (large thick arrow) in photo 5 (Bar $=5 \mu \mathrm{m})$.

The phase of regression occurred at the end of spring (November) and beginning of summer (December) with the involution of the seminiferous epithelium, meiosis and incomplete spermatogenesis. The main characteristic of this phase was the exfoliation of the seminiferous epithelium lining the tubular lumen. Thickening of the tunica albuginea and of the seminiferous tubular basement membrane, as well as a predominance of collagen fibers and various blood vessels in the interstitium was noted (Figure 2).

The testicular quiescence period started in summer (January, February) and was characterized by the presence of spermatogonia, Sertoli cells and small seminiferous tubules. The tunica albuginea and the seminiferous tubular basement membrane were thick, and a developed interstitium containing various fibroblasts and Leydig cells was noted (Figure 3).

Recrudescence occurred throughout autumn (March to June) and represented the longest period of the reproductive cycle. This phase was characterized by the recovery of the seminiferous epithelium, increase in the number of spermatogonium and the onset of meiosis, with the presence of primary spermatocytes in different stages of meiotic prophase I and maturing spermatids. The tunica albuginea and the basement membrane of the seminiferous tubules were found to be thin, and scarce interstitium containing Leydig cells was noted (Figure 4). 


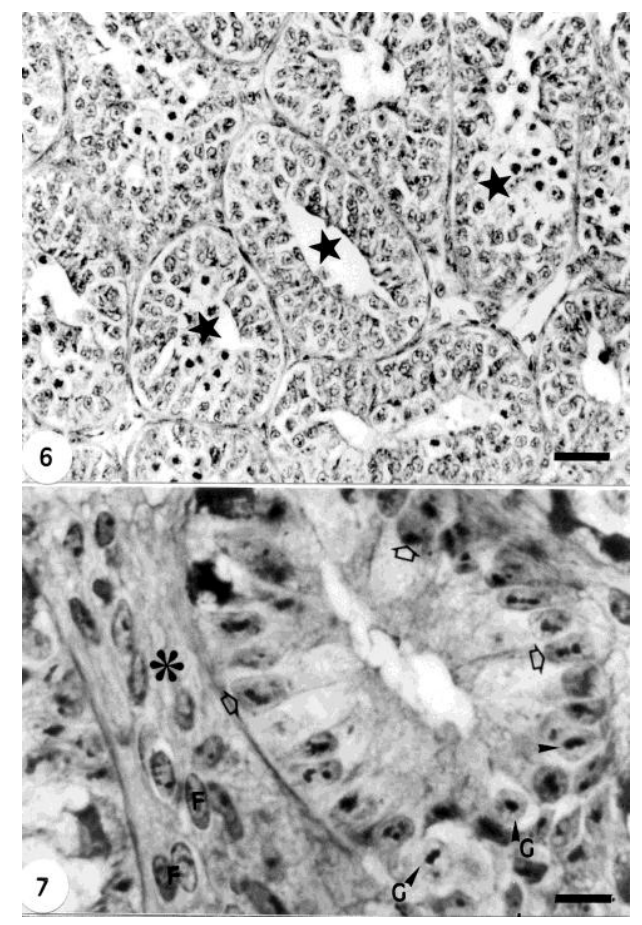

Figure 3. Phase of testicular quiescence showing small seminiferous tubules (stars) in 6 (Bar $=5 \mu \mathrm{m})$ and the seminiferous epithelium containing only spermatogonia $(G)$ and Sertoli cells (thick arrows) in 7 . Note the developed interstitium (asterisk) containing numerous fibroblasts $(\mathrm{F})$ in 7 (Bar $=2.5 \mu \mathrm{m})$.

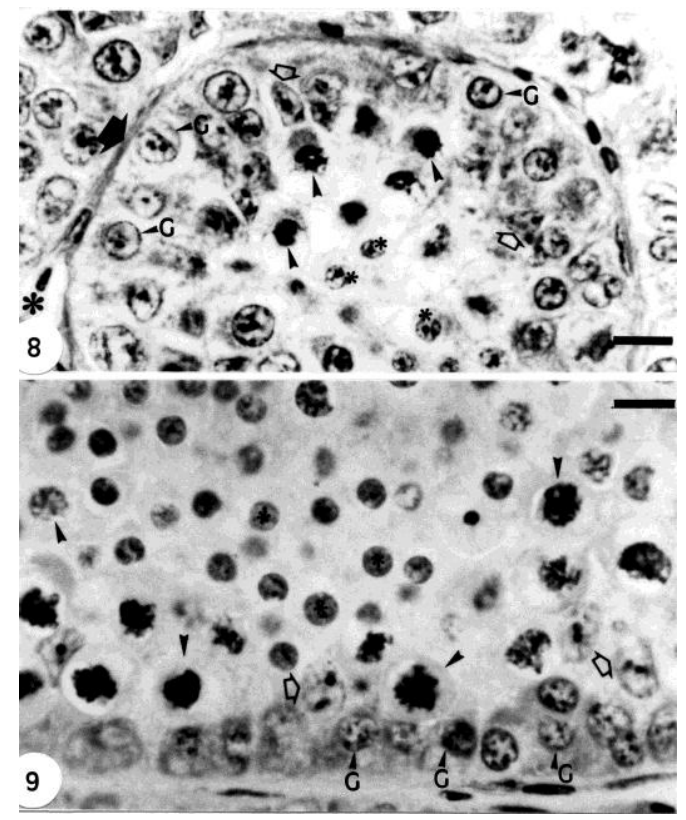

Figures 4. Phase of recrudescence showing the seminiferous epithelium containing spermatogonia $(\mathrm{G})$, primary spermatocytes (large arrowheads), round spermatids (small asterisks), Sertoli cells (thick arrows) in photos 8, 9; interstitium (large asterisk) and basement membrane (black thick arrow) in photo 8 . Bars $=2.5 \mu \mathrm{m}$. 
Throughout the reproductive phase, testicular weights (Figure 5) and the volume of the right and left testis (Figure 6) increased significantly, with maximum values in the reproductive peak (October). At this stage the seminiferous tubules were large, with larger diameters at the peak of reproduction in October (Figure 7). The variation of the height of the seminiferous epithelium followed, in general, the annual change in the diameter tubular (Figure 13). The highest values occurred in the reproductive peak (October) and in the beginning of the reproduction (July). In the remaining months of the reproductive period (August, September) intermediate height values were observed in the seminiferous epithelium (Figure 8), in the domestic duck. In the regression phase, the weights of the testes (Figure 5), testicular volume (Figure 6) was reduced. At the end of the reverse phase there was a significant increase in diameter (Figure 7) and the height of the seminiferous epithelium (Figure 8).

In the quiescence of phase both testicular weight (Figure 5), and the volume of the testis (Figure 6) had the lowest mean values and moreover, the smallest diameter (Figure 7) and lowest epithelial height (Figure 8) seminiferous tubule throughout the reproductive cycle.

In recrudescence phase testicular weight (Figure 5) and the volume of the testis (Figure 6) were reduced and the diameter of the seminiferous tubules (Figure 7) and the height of the seminiferous epithelium (Figure 8) showed lower values in relation to the other phases of the cycle. In the early recrudescence (March), the epithelial height of seminiferous tubules showed intermediate values compared to the other months of this phase (Figure 13).

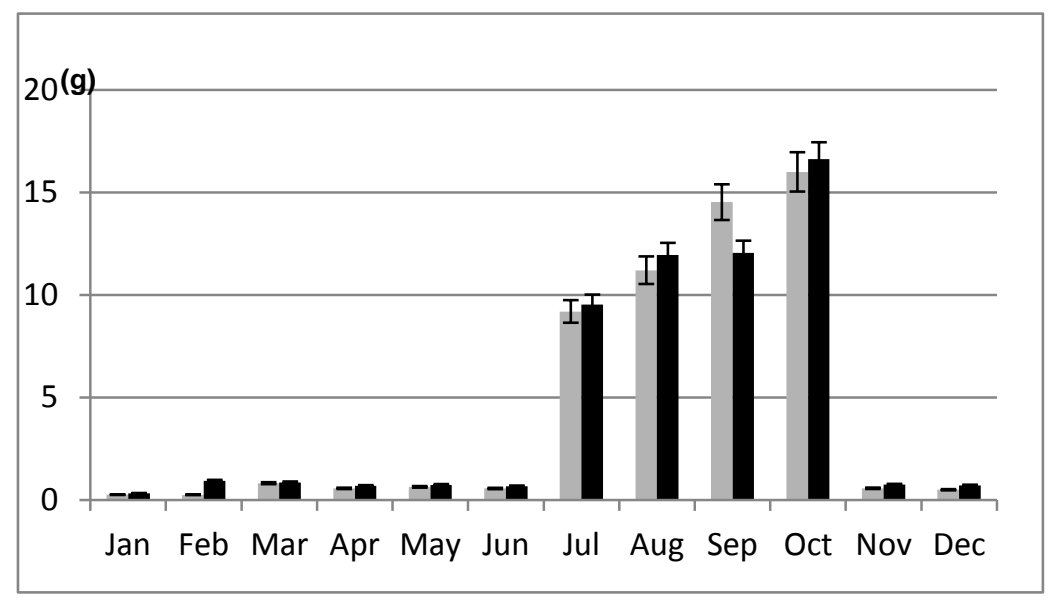

Figure 5. Variation of the absolute weight $(\mathrm{g})$ of the domestic duck testes over the year $($ Mean $\pm \mathrm{SEM}$; black $=$ left testis; gray $=$ right testis).

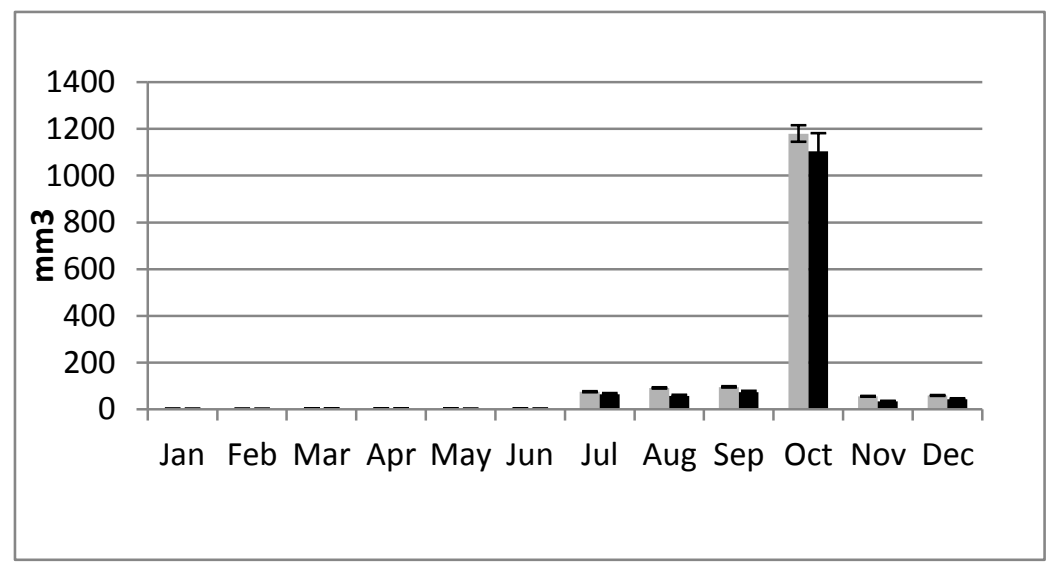

Figure 6. Testis total volume $\left(\mathrm{mm}^{3}\right)$ over the year (Mean \pm SEM; black = left testis; gray = right testis) . 


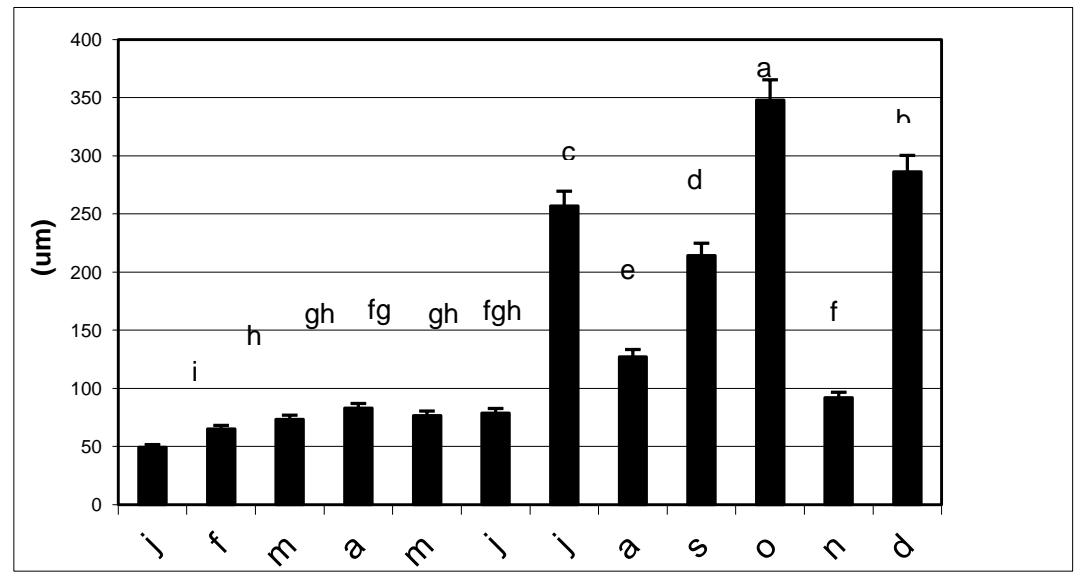

Figure 7. Variation of the diameter $(\mu \mathrm{m})$ of the seminiferous tubule of the domestic duck during the year (Mean \pm SEM).

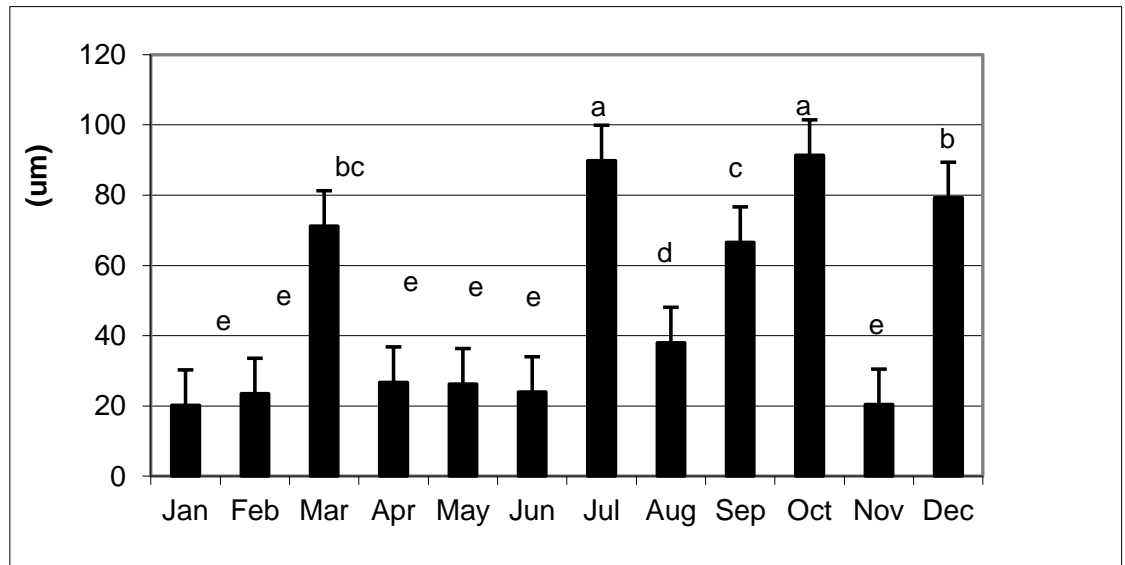

Figure 8. Variation of the height $(\mu \mathrm{m})$ of the seminiferous epithelium of the domestic duck during the year (Mean \pm SEM).

The plasma testosterone concentration of the domestic duck showed seasonal variations. The highest mean concentration was observed during peak reproduction $(76.91 \pm 0.20 \mathrm{ng} / \mathrm{dL})$, as well as at the beginning of testicular quiescence $(70.84 \pm$
$5.71 \mathrm{ng} / \mathrm{dL}$ ), with no significant difference between these two phases (Figure 9), while these values differed significantly from those observed for the other phases of the reproductive cycle.

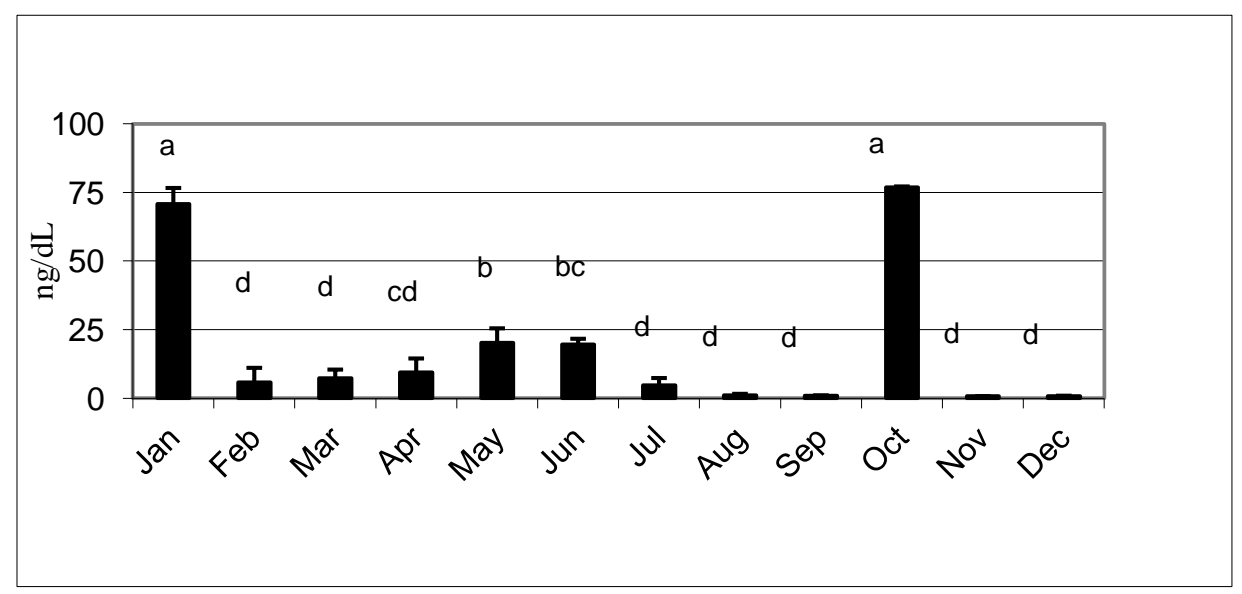

Figure 9. Mean total plasma testosterone levels (ng/dL) during the annual reproductive cycle of the domestic duck. 
Intermediate testosterone levels were observed during the recrudescence period, with no significant difference between the months of this phase. However, the lowest values in mean plasma testosterone concentration were observed between the phases of quiescence, reproduction and regression, with no significant differences between these phases (Figure 9).

\section{DISCUSSION}

The annual testicular cycle of the domestic quail has been studied by Baraldi-Artoni et al. (1997), who defined four distinct, successive and sequential phases, called quiescence (beginning of spring), recrudescence (October), activity period (end of winter, beginning of spring), and regression (end of spring, beginning of summer). These four phases resembled those described for some Passeriformes (RILEY, 1936, 1937), and an Antarctic penguin species (FUENZALIDA et al., 1989), as well as the phases and their respective durations observed in the present study for the annual testicular cycle of the domestic duck.

Morphometric parameters such as the diameter of the seminiferous tubules, height variation of the seminiferous epithelium amount of meiotic figures in this epithelium quantification of mature spermatids and spermatozoa present in the lumen of seminiferous tubules, in addition to characterization of testis weights were used to establish the annual testis cycle domestic quail (BARALDI-ARTONI et al., 1997). In this study, the quantitative parameters investigated in the domestic duck have allowed us to set an annual reproductive cycle with four distinct and successive stages, similar to the phases and their durations found in domestic quail (BARALDI-ARTONI et al., 1997) in some passerines (RILEY, 1936/37) and in Antarctic penguin (FUENZALIDA et al., 1989).

Circannual variations in spermatogenic activity have also been reported for Andean ducks (BREUCKER et al., 1989). The clearest evidence for the stage of spermatogenesis obtained in that study was an increase and/or decrease in seminiferous tubule diameter, corresponding to different phases of testicular activity and/or involution. A small reduction in seminiferous tubule diameter was observed in summer (October to December) and in winter (July to August). According to the cited study and based on the present observations, the period of reproductive activity is quite prolonged in ducks, while the phases of testicular regression and quiescence are reduced to a minimum, characterizing a cycle pattern of annual testicular activity as confirmed by Breucker et al. (1989) for Andean ducks.

Thus, the phases of reproduction and testicular recrudescence are relatively long in the domestic duck compared to the periods of gonadal regression and quiescence. As observed here, the reproductive phase started in winter (July) and was extended until August of the following winter, reaching its maximum peak in spring (October), with this phase being characterized by complete spermatogenic activity. The period of regression started in November, at the end of spring, with exfoliation of the seminiferous epithelium, while testicular quiescence occurred in January and February, during the summer season, and was characterized by the presence of spermatogonia and Sertoli cells in the seminiferous epithelium. In contrast, the phase of recrudescence was extended throughout autumn, comprising the months from March to June, with recovery of the seminiferous epithelium, characterizing incomplete spermatogenesis but with preparation for the subsequent reproductive phase. These findings are species specific and are reported here for the first time.

The annual reproductive cycle of the European swan (Cygnus olor) sexually active was observed by Breucker (1982) considered that the increase and decrease the diameter of the seminiferous tubules as a parameter for assessing the spermatogenic activity. The diameter of the seminiferous tubules of the European swan showed a progressive increase in winter and highest in the spring breeding period, with a subsequent decrease in summer and autumn, periods of regression and gonadal quiescence. In the domestic duck, the larger diameter of the seminiferous tubules were observed throughout the reproductive phase (winter and spring), with a peak in October, and also in the regressive phase (summer season) similar to that found for the domestic quail (BARALDI- ARTONI et al., 1997). Regarding the epithelial height it was observed variation similar to the tubular diameter, except for the beginning of the recrudescence phase (March) which showed intermediate values, indicating the start of the recovery of the seminiferous epithelium through meiotic division processes of spermatocytes and differentiation of spermatids.

The annual cycle of the Plectropterus gambensis goose was described by Halse (1985), the African continent, with nine recognized spermatogenic stages, based on variation of testicular parameters. The testicular weight showed pronounced changes during the annual cycle. 
Therefore, its increase was accompanied by enlargement of the seminiferous tubules, due to the increase in spermatogenic activity. The Intertubular interstitium also changed during the year, but in the opposite direction to the testicular weight and diameter of the tubules. In the domestic duck, the highest weight values and testicular volume were found throughout the reproductive phase, with a peak in October, similar to that found for the domestic quail (BARALDI-ARTONI et al., 1999).

Studies conducted on European swans (BREUCKER, 1982) and domestic quails (BARALDI-ARTONI et al., 1997) have demonstrated the presence of a period of higher reproductive activity in spring, although spermatozoa were observed in swans only during a few weeks. In contrast, maturing spermatids and spermatozoa, with small variations, were observed in quail testes throughout the year. According to Baraldi-Artoni et al. (1997), this difference in spermatozoon production is probably due to variations in climatic conditions between the southern and northern hemispheres. In the present study on the domestic duck, spermatozoon production was observed throughout winter (July, August), and also in spring (September, October) when it reached its maximum peak.

Some bird species show an annual reproductive cycle and cyclic variations in reproductive hormones associated with structural changes in the testes and spermatogenic cells. Androgens play an important role in avian reproduction, with modifications in plasma androgen levels paralleling changes in the spermatogenic activity of the testes (KIM, YANG, 2001).

Hau et al. (2000), analyzing the plasma testosterone levels, reproductive behavior and reproductive cycle of Hylophylax naevioides (Passeriformes), observed that testosterone levels increased at the beginning of spring and remained elevated throughout the reproductive period, but this situation was not observed in the domestic duck. According to these authors, in this restricted territorial species, testosterone, in addition to triggering an aggressive behavior during courtship and mating, is important for the expression of secondary sexual traits, spermatozoon production and typical male sexual behavior.

Seasonal variations in gonadal activity have been observed for different wild bird species inhabiting temperate regions as a consequence of interaction between environmental and hormonal factors (TSUTSUI et al., 1994). In these species, LH and sex steroid concentrations increase in spring, remain relatively high during the reproductive phase, and decline to basal levels at the end of reproduction (BALL, WINGFIELD, 1987).

The domestic duck showed seasonality in plasma testosterone levels, with the highest levels being observed during peak reproduction and at the beginning of quiescence. A similar hormonal pattern has been reported for the subtropical bird Ploceus philippinus (TSUTSUI et al., 1994) and also for the canary Serinus canarius (NOTTEBOHM et al., 1987).

We observed here for the first time that in the domestic duck the peak testosterone concentration showed during the initial quiescence period and it might be related with the spermatogonium proliferation, characterizing this phase, and the presence of various Sertoli cells. After the onset of spermatogonium proliferation, testosterone levels decreased until the reproductive phase in August despite the fact that testosterone is involved in the processes of spermatogenesis and cell proliferation. In contrast, the large increase in plasma testosterone levels observed during peak reproduction might be related to the behaviors of female courting and aggressiveness during territorial defense which are characteristic of the reproductive period. These affirmations agree with previous descriptions (HAU et al., 2000; WIKELSKI et al., 2000; HAU, 2001).

Recent studies on the endocrine control of seasonal reproductive behavior in tropical birds revealed that testosterone regulates male aggressive behavior in territorial birds (HAU et al., 2000; WIKELSKI et al., 2000; HAU, 2001). According to these authors, testosterone is often produced during the non-reproductive phase, whose gonads probably secrete this hormone even during the stage of testicular regression as observed here for the domestic duck. Alternatively, testosterone precursors might arise from non-gonadal sources (WIKELSKI et al., 1999; SOMA et al., 2000) and are converted into testosterone at cerebral target sites (SCHLINGER, ARNOLD, 1992; SOMA, WINGFIELD, 1999; HAU et al., 2000; SOMA et al., 2000).

RESUMO: Alterações morfofuncionais gonadais constituem um ciclo anual em aves durante o qual quatro fases podem ser distinguidas nos testículos, com base em modificações histológicas no epitélio seminífero, chamados de 
repouso, recrudescência, proliferação e regressão. O objetivo do presente estudo foi realizar um estudo morfológico e morfométrico do epitélio seminífero no testículo de pato doméstico e avaliar os níveis de testosterona plasmática, a fim de determinar a possível presença de um ciclo reprodutivo na região tropical. O estudo foi conduzido em 60 patos domésticos adultos (Anas platyrhynchos), onde cinco animais foram sacrificados por mês e os testículos foram removidos e estudados histologicamente e morfometricamente. As amostras de sangue dos cinco animais foram coletadas mensalmente no período da manhã e os níveis de testosterona foram analisados. O ciclo reprodutivo anual do pato doméstico apresentou quatro fases distintas, iniciando com a fase reprodutiva no início do inverno (julho) e pico de reprodução na primavera (outubro), acompanhado por um aumento no diâmetro dos túbulos seminíferos, na altura do epitélio, no peso e no volume dos testículos e, seguido de uma fase regressiva no final da primavera (novembro) e no início do verão (dezembro). A quiescência testicular foi observada durante o verão (janeiro e fevereiro) e seguida por uma fase de recrudescência espermatogênica, a qual perdurou durante o outono (Março a Junho), que correspondeu à fase mais longa do ciclo. A espermatogênese completa, em termos de maturação dos espermatozóides e espermiação, foi observada durante a fase de reprodução, que coincidiu com o pico de testosterona no plasma. Na fase regressiva foi observada uma esfoliação do epitélio seminífero, acompanhada por aumento na quantidade de colágeno fibrilar. Um decréscimo no diâmetro dos túbulos seminíferos e na altura do epitélio seminífero foram observados durante a quiescência testicular, com predomínio de espermatogônias e células de Sertoli e, um segundo pico de testosterona plasmática, também foi observado durante essa fase (Janeiro), provavelmente representando a preparação para um retorno gradual ao processo espermatogênico durante a recrudescência. Esta última fase foi caracterizada pela recuperação gradual do epitélio seminífero, acompanhada pelo aumento de espermatogônia, início da meiose, e a presença de espermatócitos primários e espermátides em maturação. Em conclusão o pato doméstico apresentou o ciclo testicular dividido em quatro fases distintas na região tropical, com picos de testosterona nas fases reprodutiva e de quiescência testicular.

PALAVRAS-CHAVE: Ciclo reprodutivo. Testosterona. Pato doméstico.

\section{REFERENCES}

BALL, G. F.; WINGFIELD, J. C. Changes in plasma levels of luteinizing hormone and sex steroid hormones in relation to multiple-broodedness and nest-site density in male starlings. Physiol. Zool, Chicago, v. 60, p. 191199, 1987. https://doi.org/10.1086/physzool.60.2.30158643

BARADI-ARTONI, S. M. B.; ORSI, A. M.; LAMANO-CARVALHO, T. L.; LOPES, R. A. The annual testicular cycle of the domestic quail (Coturnix coturnix japonica). Anat. Histol. Embryol, Berlin, v. 26, p. 337-339, 1997. https://doi.org/10.1111/j.1439-0264.1997.tb00145.x

BARADI-ARTONI, S. M. B.; ORSI, A. M., LAMANO-CARVALHO, T. L.; VICENTINI, C. A.; STEFANINI, M. A. Seasonal morphology of the domestic quail (Coturnix coturnix japonica) testis. Anat. Histol. Embryol, Berlin, v. 28, p. 217-20, 1999. https://doi.org/10.1046/j.1439-0264.1999.00168.x

BENTLEY, P. J. Hormones and reproduction. In: BENTLEY, P. J. Comparative Vertebrate Endocrinology. London: Cambrige University Press, 1998. p. 379-440.

BREUCKER, H. Seasonal spermatogenesis in the mute swan (Cygnus olor). Anat. Embryol. Cell Biol, Berlin, v. 72, p. 1-91, 1982. https://doi.org/10.1007/978-3-642-68460-9_1

BREUCKER, H.; SCHAFER, E.; OBREGON, E. B. Spermatogenesis of Lophonetta specularioides (Anatidae, Aves) in the high plateau of the southern Andes. A light and electron microscopic study. Micr. Electr. Biol. Cel, Mendoza, v. 13, p. 167-182, 1989.

FARNER, D. S.; FOLLETT, B. K., Reproductive periodicity in birds. In: BARRINGTON, E.J.W. Hormones and Evolution. New York: Academic Press, 1979. p. 829-872.

https://doi.org/10.1146/annurev.ph.47.030185.000433

FARNER, D. S. Annual rhythms. Annu. Rev. Physiol, Palo Alto, v. 47, p. 65-82, 1985.

FARNER, D. S.; GWINNER, E. Photoperiodicity, circannual and reproductive cycles. In: EPPLE, A.; STETSON, M. H. Avian Endocrinology. New York: Academic Press, 1980, p. 332-366. 
FOLLETT, B. K. Birds. In: LAMMING, G. E. Marshall's Physiology and Reproduction. New York: Churchill-Livingstone, 1984. p. 283-350.

FUENZALIDA, H.; LEYTON, V.; VALENCIA, J.; BLANQUEZ, M. J.; GONZALEZ, M. E. Morfologia del testículo de Pygoscelis papua (Foster) durante el período de actividad sexual. Arch. Anat. Embryol, Berlin, v. 20, p. 79-91, 1989.

HALSE, S. A. Gonadal cycles and levels luteinizing hormone in wild Spur-winged geese, Plectropterus gambensis. J. Zool, London, v. 205, p. 35-55, 1985. https://doi.org/10.1111/j.1469-7998.1985.tb05621.x

HAU, M.; WIKELSKI, M.; SOMA, K.; WINGFIELD, J. C. Testosterone and year-round territoriality in a tropical bird. Gen. Comp. Endocrinol, New York , v. 117, p. 20-33, 2000.

https://doi.org/10.1006/gcen.1999.7390

HAU, M. Timing of breeding in variable environments: tropical birds as model systems. Horm. Behav, Atlanta, v. 40, p. 281-290, 2001. https://doi.org/10.1006/hbeh.2001.1673

KEMP, A. C. Environmental factors affecting the onset breeding in some Southern African hornbills, Tockus spp. J. Reprod. Fertil, London, v. 19, p. 319-331, 1973.

KIM, I. S.; YANG, H. H. Seasonal changes of testicular weight, sperm production, serum testosterone, and in vitro testosterone release in Korean ring-necked pheasants (Phasianus colchicus karpowi). J. Vet. Med. Sci, Tokyo, v. 63, p. 151-156, 2001. https://doi.org/10.1292/jvms.63.151

LESKA, A.; KIEZUN, J.; KAMINSKA, B.; DUSZA, L. Seasonal changes in the expression of the androgen receptor in the testes of the domestic goose (Anser anser f. domestica). Gen. Comp. Endocrinol, New York, v. 179, n. 1, p. 63-70, 2012. https://doi.org/10.1016/j.ygcen.2012.07.026

LORMÉE, H.; JOUVENTIN, P.; LACROIX, A.; LALLEMAND, J.; CHASTIL, O. Reproductive endocrinology of tropical seabirds: sex-specific patterns in LH, steroids, and prolactin secretion in relation to parental care. Gen. Comp. Endocrinol, New York, v. 117, p. 413-426, 2000.

https://doi.org/10.1006/gcen.1999.7434

MCDOWELL, E. M.; TRUMP, B. F. Histologic fixatives suitable for diagnostic light and electron microscopy. Arch. Pathol. Lab. Med, Chicago, v. 100, p. 405-414, 1976.

MIRAGLIA, S. M.; HAYASHI, H. Histomorphometry of immature rat after heating. J. Morphol, Malden, v. 217, p. 65-74, 1993.

NOTTEBOHM, F.; NOTTEBOHM, M. E.; CRANE, L. A.; WINGFIELD, J. C. Seasonal changes in gonadal hormone levels of adult male canaries and their relation to song. Behav. Neural Biol, New York, v. 47, p. 197211, 1987. https://doi.org/10.1002/jmor.1052170106

RILEY, G. M. Experimental studies on spermatogenesis in the house sparrow, Passer domesticus (Linnaeus). Anat. Rec, New York, v. 67, p. 327-351, 1936, 1937.

SCHLINGER, B. A.; ARNOLD, A. P. Circulating estrogens in a male songbird originate in the brain. Proc. Natl. Acad. Sci, Bethesda, v. 89, p. 7650-7653, 1992. https://doi.org/10.1073/pnas.89.16.7650

SILVERIN, B. Reproductive organs and breeding behavior of the male pied Flycatcher Ficedula hypoleuca (Ballas). Ornis Scand, Copenhagen, v. 6, p. 15-26, 1975. https://doi.org/10.2307/3676275

SOMA, K. K.; WINGFIELD, J. C. Endocrinology of aggression in the non-breeding season. Ornithol. Cong, Durban, v. 1, p.1606-1620, 1999. https://doi.org/10.1098/rspb.2000.1113 
SOMA, K. K.; TRAMONTIN, A. D.; WINGFIELD, J. C. Oestrogen regulates male aggression in the nonbreeding season. Proc. R. Soc. Lond, London, v. 267, p. 1089-1096, 2000.

TSUTSUI, K.; SAXENA, T.; SAXENA, R. N. Effects of season and photoperiod on the plasma and intratesticular testosterone levels in Indian weaverbirds inhabiting the subtropical zone. J. Exp. Zool, Austin, v. 270, p. 381-87, 1994. https://doi.org/10.1002/jez.1402700407

WIKELSKI, M.; HAU, M.; ROBINSON, D. W.; WINGFIELD, J. C. Seasonal endocrinology of tropical passerines. A comparative approach. Ornithol. Cong, Durban, v. 1, p. 1224-1241, 1999.

WIKELSKI, M.; HAU, M.; WINGFIELD, J. C. Seasonality of reproduction in a neotropical rainforest bird. Ecology, Washington, v. 81, p. 2458-2472, 2000. https://doi.org/10.1890/00129658(2000)081[2458:SORIAN]2.0.CO;2

WINGFIELD, J. C. Environmental and endocrine control of avian reproduction: an ecological approach. In: MIKAMI, S.; HOMMA, K.; WADA, M. Avian Endocrinology. Tokyo: Springer-Verlag, 1983. p. 265-288.

WINGFIELD, J. C.; FARNER, D. S. Endocrinology of reproduction in wild species. In: FARNER, D. S.; KING, J. R.; PARKES, K. C. Avian Biology. New York: Academic Press, 1983. p. 163-327.

WINGFIELD, J. C.; HEGNER, R. E.; DUFTY, A. M.; BALL, G. F. The "challenge-hypothesis": Theoretical implications for patterns of testosterone secretion, mating systems, and breeding strategies. Am. Nat, Chicago, v. 136, p. 829-46, 1990. https://doi.org/10.1086/285134 